\title{
EPIDENDRUM CURIMARCENSE (ORCHIDACEAE), A NEW SPECIES FROM CENTRAL PERU
}

\author{
Wendy Carolay Navarro Romo ${ }^{1,2,4}$, Harold Rusbelth Quispe-MelgaR ${ }^{1}$ \\ \& ERIC HÁGSATER ${ }^{3}$
}

\author{
${ }^{1}$ Programa de Investigación de Ecología y Biodiversidad, Asociación ANDINUS, Calle Miguel Grau \\ 370, Sicaya, Huancayo, Junín, Perú \\ ${ }^{2}$ Facultad de Ciencias Forestales y del Ambiente, Universidad Nacional del Centro del Perú, Avenida \\ Mariscal Castilla 3909, Huancayo, Junín, Perú \\ ${ }^{3}$ Herbario AMO, Montañas Calizas 490, Miguel Hidalgo, CDMX, 11000, México \\ ${ }^{4}$ Author for correspondence: w.navarro.romo@gmail.com
}

\begin{abstract}
A new species of Epidendrum from Peru, Epidendrum curimarcense, is described, illustrated and compared with the similar species Epidendrum ampelospathum. The new finding represents an important record for the flora associated with Polylepis forests of central Peru. The species has stems produced from a middle internode of the previous cane-like stem, a spathe, an elongate peduncle with several similar spaced bracts, flowers opening in succession, petals narrower than the sepals, a 3-lobed lip which is bicallose with rounded sub-equal lobes, and 4 obovoid, laterally compressed pollinia.

Resumen. Una nueva especie de Epidendrum del Perú, Epidendrum curimarcense, es descrita, ilustrada y comparada con la especie similar Epidendrum ampelospathum. El nuevo hallazgo representa un importante registro para la flora asociada a bosques de Polylepis en el centro del Perú. La especie tiene tallos tipo caña producidos de un internodo medio del tallo anterior, una espata en la base de la inflorescencia, con varias brácteas semejantes espaciadas a lo largo del pedúnculo alargado, las flores abren en sucesión, los pétalos son más angostos que los sépalos, labelo 3-lobado, lóbulos redondeadas semejantes, bicalloso; polinios 4, obovoides, lateralmente comprimidos.
\end{abstract}

Key Words / Palabras clave: Andean orchids, central Peru, Epidendrum, Junín, orquídeas andinas, Polylepis

Introduction. The Epidendrum genus was assigned by Linnaeus in 1763, for all orchids that grew on trees. None of the early species designated by Linnaeus remain today in the genus, as orchids are predominantly epiphytic, so many genera were later described, and all the original species placed in them. In the early botanical expeditions to Peru and Chile, Ruiz and Pavón (1798) published 19 species of Epidendrum based on their collections and their illustrations which are deposited in Real Jardín Botánico de Madrid Herbarium (MA).

Epidendrum is one of the most diverse genera within the Orchidaceae family, distributed from sea level to 4,200 meters altitude (Hágsater \& Soto 2005). Epidendrum are epiphytic, lithophytic, or rarely terrestrial herbs, caespitose, sympodial or rarely monopodial, and then usually branching above, erect, creeping or hanging. The stems are usually cane-like, simple or branching, sometimes thickened and then fusiform, rarely pseudobulbous. The inflorescence is apical, lateral, or rarely basal, single-flowered, subcorymbose, racemose to paniculate, producing flowers only once, or producing new racemes from an old inflorescence over several years, thus producing in time a pluri-racemose structure from what was a racemose inflorescence at first flowering, sessile to long-pedunculate, when apical often produced from within one or two spathaceous bracts that develop long before the inflorescence. The labellum is, in most species, united to the column lateral margins along the entire length of the column, however some groups of Epidendrum species have labella that are partially to totally free. The column-labellum structure forms a nectar tube that usually penetrates the ovary. The labellum is usually ornate with two basal, globose calli and a pair of laminar calli ending in a narrow keel or a complex, tuberculate callus; however, some species lack any callus and instead have one or several parallel 
to radiating keels, sometimes ornate with trichomes or papillae. The labella range from entire to deeply 3- or 4-lobed, mostly distinct from the sepals and petals. The pollinarium usually has 4 pollinia, rarely 2 or 8 . The rostellum is parallel to the longitudinal column axis, arching downwards at the apex, producing a semi-liquid viscidium attached to the caudicles of the pollinarium as it is removed from the column during pollination, leaving an elliptical slit.

Agricultural expansion, cattle ranching, logging, burning, among other human activities are the main causes of habitat loss of Epidendrum and other types of plants that are dependent on trees (García \& Galeano 2006).

Peru was credited with around 2034 species of orchids (Brako \& Zarucchi 1993, Ulloa, Zarucchi \& Léon 2004), among them 775 endemics, 98 of the endemics correspond to the genus Epidendrum with only 14 species registered for the Junín region (Roque \& León 2006). Ulloa et al. (2017) published a new number of 2,120 species for Peru, including 316 species of Epidendrum. Several additions have been made since 2017 (Damian \& Hágsater 2016, Hágsater \& Santiago 2018a, 2018b, Acuña-Tarazona et al. 2019, Gutierrez et al. 2019). The most recent publication of Hágsater and Santiago (2019) includes 18 new species from Peru; several, including some old species, cited for Junín (Epidendrum choccei M.E.Acuña, Hágsater \& E.Santiago, E. trullatum Hágsater, L.Valenz. \& E.Santiago, E. holochilum (Schltr.) Mansf. ex Hágsater and E. megagastrium Lind1.). These, including the new species here described, would increase the orchids numbers to 2142 for Peru, and 338 for Junín. Hágsater, in the AMODATA digital information bank (2019), has registered 439 species of Epidendrum for Peru (Santiago \& Hágsater 2019, Goicochea et al. 2019). A count of orchid species prepared by Ulloa (2019) from the Vascular Plants of the Americas - Tropicos sets the number of orchids at 2219 of which 355 are Epidendrum species. That list corrected by Hágsater in late November 2019 (unpubl. data), deleting incorrect citations, synonyms and adding recently published species not yet included in Tropicos, sets the number of Epidendrum species for Peru at 446. Current work by a team of Peruvian botanists will probably greatly increase that number of species.
This work, along with work in herbaria and in the field, is proving that species thought to be endemic to either Colombia, Ecuador, Peru or Bolivia, are in reality more widespread, and thus the number of species is increasing but endemism may be less frequent (Hágsater unpubl. data).

High altitude Andean forests (3000-5200 m, Kessler 2006) harbor diversity and very high rates of endemic species of flora and fauna (Fjeldså \& Kessler 2004). In the last decade, several new records have been made for the Epidendrum genus throughout the Andes as more areas that were not previously wellexplored are being examined, thus demonstrating that the Epidendrum genus possesses much greater diversity than previously estimated. This article describes and illustrates a new species for the Department of Junín of Peru.

Materials and methods. The plant material was collected in Curimarca, Molinos District, Jauja Province, Junín Department (Fig. 1) in fieldwork in which the flora associated with the high Andean forests of Polylepis was evaluated. Photographs were taken in the field and laboratory for preparing and diagramming a Lankester Composite Digital Plate (LCDP). Searches were made in AMODATA, where 691 records were retrieved for Epidendrum from Junín, out of a total of 10,165 for Peru. Other herbaria recorded include AMES, AMO, B (photographs lodged at F), CAS, COL, F, G, GH, HB, HBG, HOXA, K, LE, LL, M, MA, MO, MOL, NY, OXF, P, PR, RENZ, S, SEL, TNS, UC, US, USM and WIS. These records are based on images taken at these herbaria through the years and do not necessarily include recent collections. Records of specimens and illustrations from David E. Bennet Jr. (at MOL and AMO) were also searched. The records for Junín were studied for possible matches. Comparisons were made with E. ampelospathum Hágsater \& Dodson (2004) and E. ampelomelanoxeros Hágsater, E.Santiago \& E.Parra (2013) (images of type and live material at AMO, as well as descriptions), the species most similar vegetatively to $E$. curimarcense. In addition, due to the floral and inflorescence details, the species was also compared to Epidendrum totoroense J.S.Moreno, Hágsater, E.Santiago \& Erazo (2016). The pressed material was deposited at HOXA and HUT herbaria. 


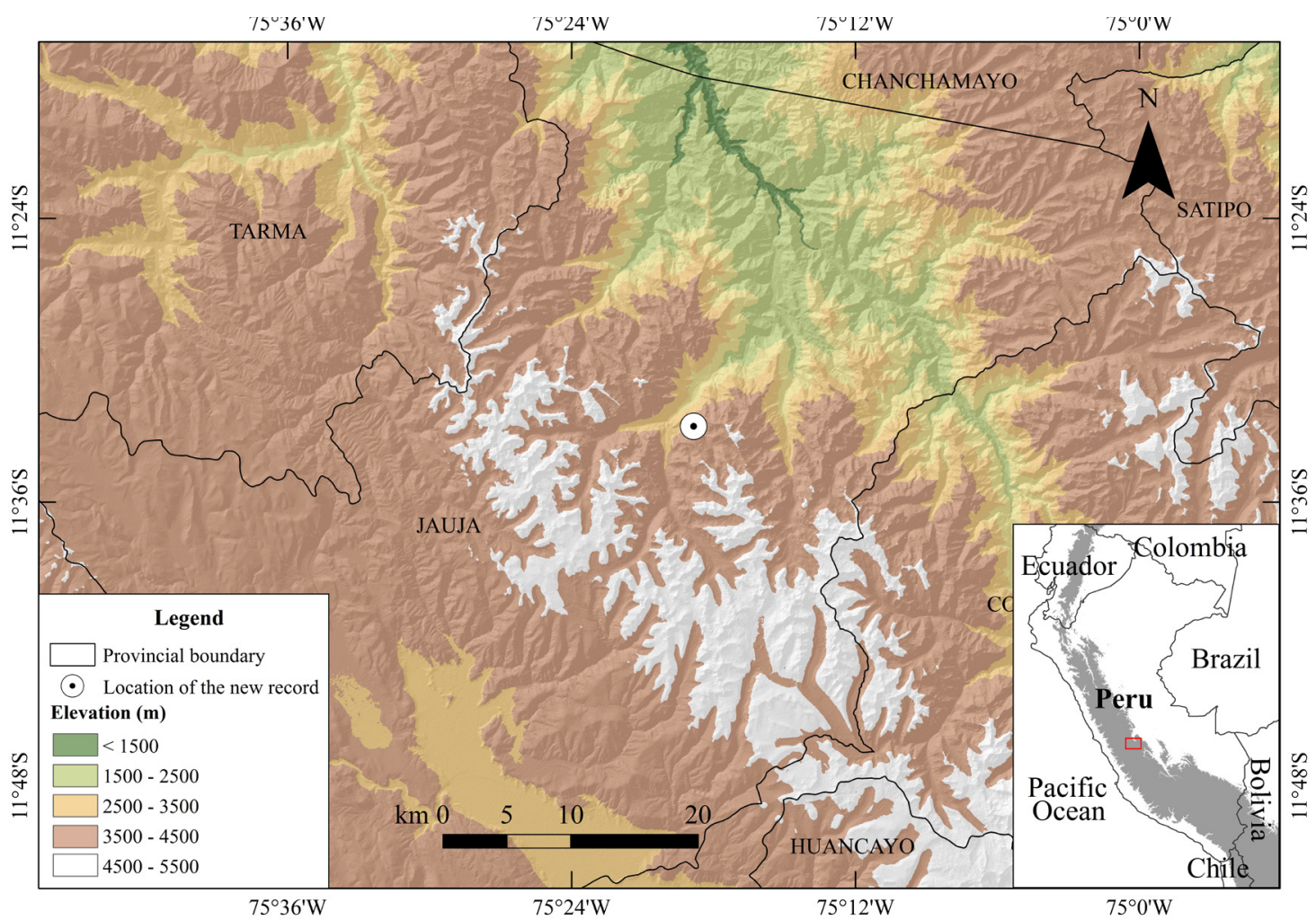

FIGURE 1. Distribution map of Epidendrum curimarcense (white circle) in Peru.

\section{TAXONOMIC TREATMENT}

\section{Epidendrum curimarcense Hágsater, W.C.Navarro \&} H.R.Quispe, sp. nov. (Fig. 2-3)

TYPE: Peru. Junín: Jauja Province, Molinos District; Curimarca River, $3450 \mathrm{~m}$, humid montane forest, epiphyte on Polylepis canoi W.Mend., Oreopanax oroyanus Harms, and Miconia sp., collected 17 March 2018, pressed 20 March 2018, W. C. Navarro \& H. R. Quispe 050. Holotype HOXA! (LCDP \& photo voucher). Isotype HUT!

Diagnosis: Epidendrum curimarcense is similar to $E$. ampelospathum Hágsater \& Dodson, but plants are much smaller, to $30 \mathrm{~cm}$ tall, elliptic leaves, 2.5-7.3 $\times$ $1.0-2.5 \mathrm{~cm}$, inflorescence $17.5 \mathrm{~cm}$ long with a spathe $2.3 \times 0.5 \mathrm{~cm}$, peduncle elongate, ancipitose, provided with $2-3$ bracts similar to the spathe but progressively shorter, flowers greenish buff, column and lip green, sepals $16 \times 4-5 \mathrm{~mm}$, petals oblanceolate, $12.0 \times$
$2.5 \mathrm{~mm}$, and lip base slightly cordate, lateral lobes transversely ovoid; mid-lobe sub-quadrate.

Epiphytic, sympodial, scandent, erect to arching herb, ca. $30 \mathrm{~cm}$ long, of successive lateral growths. Stems $10-14 \times 0.3-0.4 \mathrm{~cm}$, produced from a middle internode of the previous stem (2nd to 4th internode, below the first leaf), cane-like, terete. Leaves 5-6 distributed throughout the upper half of the stem, spreading, sub-coriaceous; sheath $1.0 \times 0.4 \mathrm{~cm}$, tubular; blade $2.5-7.3 \times 1.0-2.5 \mathrm{~cm}$, elliptic, acute, smooth, margin entire, spreading. Spathe $2.3 \times 0.5$ $\mathrm{cm}$, single, conduplicate, tubular below, open above, narrowly elliptic, acuminate, margin entire, light brown. Inflorescence $17.5 \mathrm{~cm}$ long, apical, racemose, arching, nutant, flowering only once; peduncle $5-8 \mathrm{~cm}$ long, elongate, ancipitose, provided with $2-3$ bracts, up to $23 \times 5 \mathrm{~mm}$, similar to the spathe but progressively smaller and developed as the inflorescence grows, conduplicate, tubular below, open above, narrowly elliptic, acuminate, margin entire, light brown. 

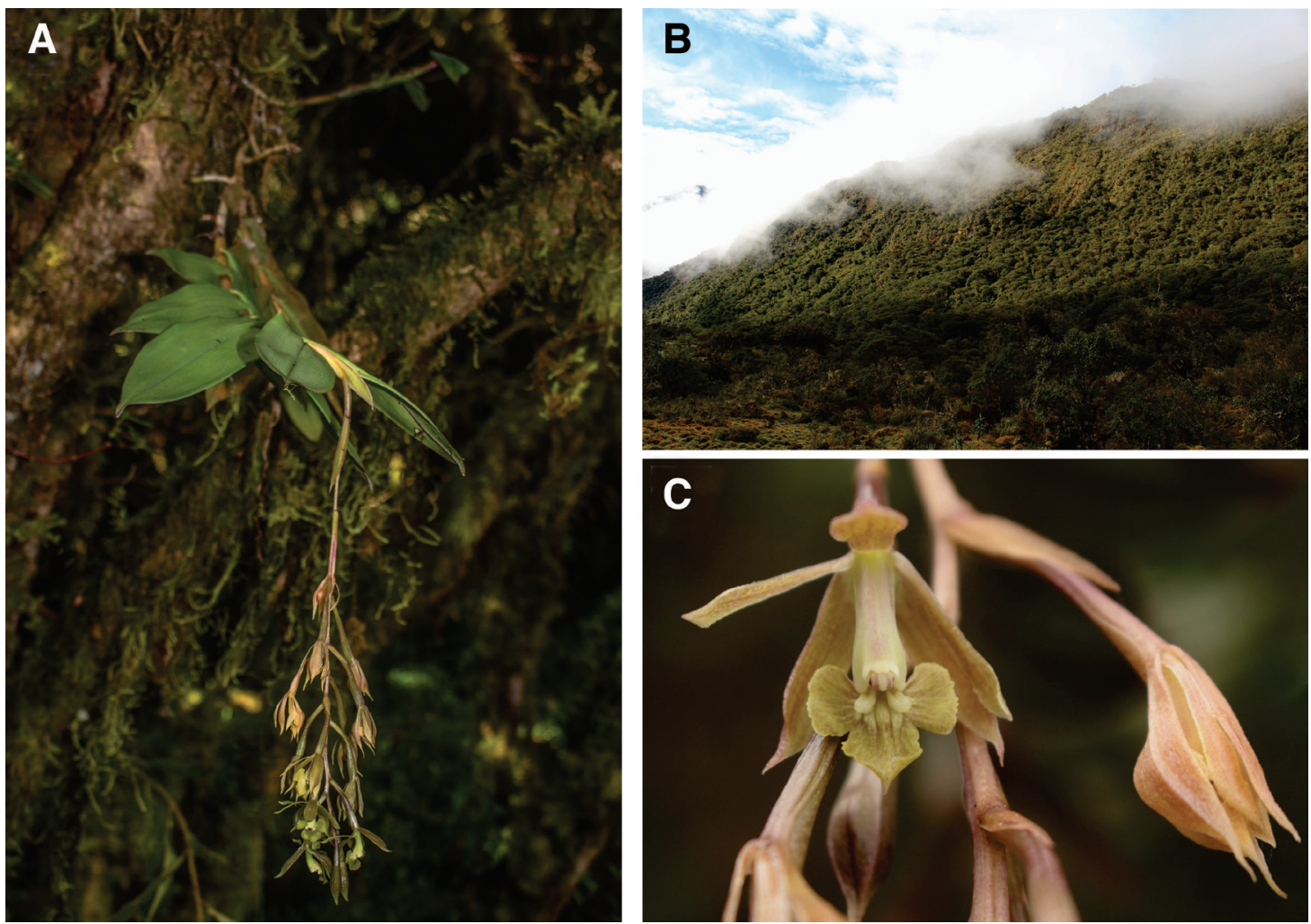

Figure 2. Epidendrum curimarcense. A. Habit and complete plant. B. Habitat. C. Flowers. Photograph by Harold R. Quispe-Melgar.

Floral bracts $5-8 \times 1 \mathrm{~mm}$, shorter than the ovary, triangular, acute. Flowers $6-15$, opening in succession, eventually most open together, greenish buff (turning reddish brown as they wilt), column and lip green; without fragrance. Ovary 12.5-16.0 mm long, terete, progressively thickened towards the apex. Sepals partly spreading, 3-veined, long apiculate, margins entire; dorsal sepal $16 \times 4 \mathrm{~mm}$, free, oblong, widened slightly near the apex, acuminate; lateral sepals 16 $\times 5 \mathrm{~mm}$, obliquely united to the base of the column, obliquely oblong-obovate, acuminate. Petals $12.0 \times$ $2.5 \mathrm{~mm}$, partly spreading, free, oblanceolate, acute, somewhat oblique, the upper margin straight, 1-veined, margin entire. Lip $9 \times 10 \mathrm{~mm}$, united to the column, 3-lobed, the base slightly cordate, margin entire to erose, bicallose, the calli divergent, prominent, digitiform, a low fleshy mid-rib runs down the middle of the mid-lobe to the apex with a pair of lower, shorter ribs on the side; lateral lobes $3 \times 5 \mathrm{~mm}$, transversely ovoid, rounded; mid-lobe $4 \times 5 \mathrm{~mm}$, sub-quadrate, apex rounded. Column $10 \mathrm{~mm}$ long, thick, straight, apex truncate; clinandrium hood short, margin entire. Anther reniform, 4-celled. Pollinia obovoid, laterally compressed; caudicles granulose, short; viscidium semi-liquid. Rostellum apical, slit. Lateral lobes of the stigma short, the viscidium itself also short, about the same size as the clinandrium. Nectary penetrating half the ovary, smooth, not inflated, unornamented. Capsule $46 \times 19 \mathrm{~mm}$, ellipsoid, pedicel $7 \mathrm{~mm}$ long, short thin, body $36 \times 19 \mathrm{~mm}$, and neck ca. $3 \mathrm{~mm}$ long.

Distribution AND ECOLOGY: Known presently only from the type, from central Peru, Department of Junín, upper basin of the Río Curimarca, an affluent of the Río Uchubamba, on the upper eastern slopes of the Cordillera Oriental de Los Andes. In montane

$\rightarrow$ Right, Figure 3. Plate of Epidendrum curimarcense. A. Habit and inflorescence. B. Plant in fruit. C. Dissected perianth. D. Column and lip. E. Anther. F. Pollinarium. G. Column, dissected and lateral view. H. Column and lip, lateral view. I. Flower, front view. Photographs by Jonathan Chancasana (C, E, F \& G) and Harold R. Quispe-Melgar (A, B, D, H \& I). 


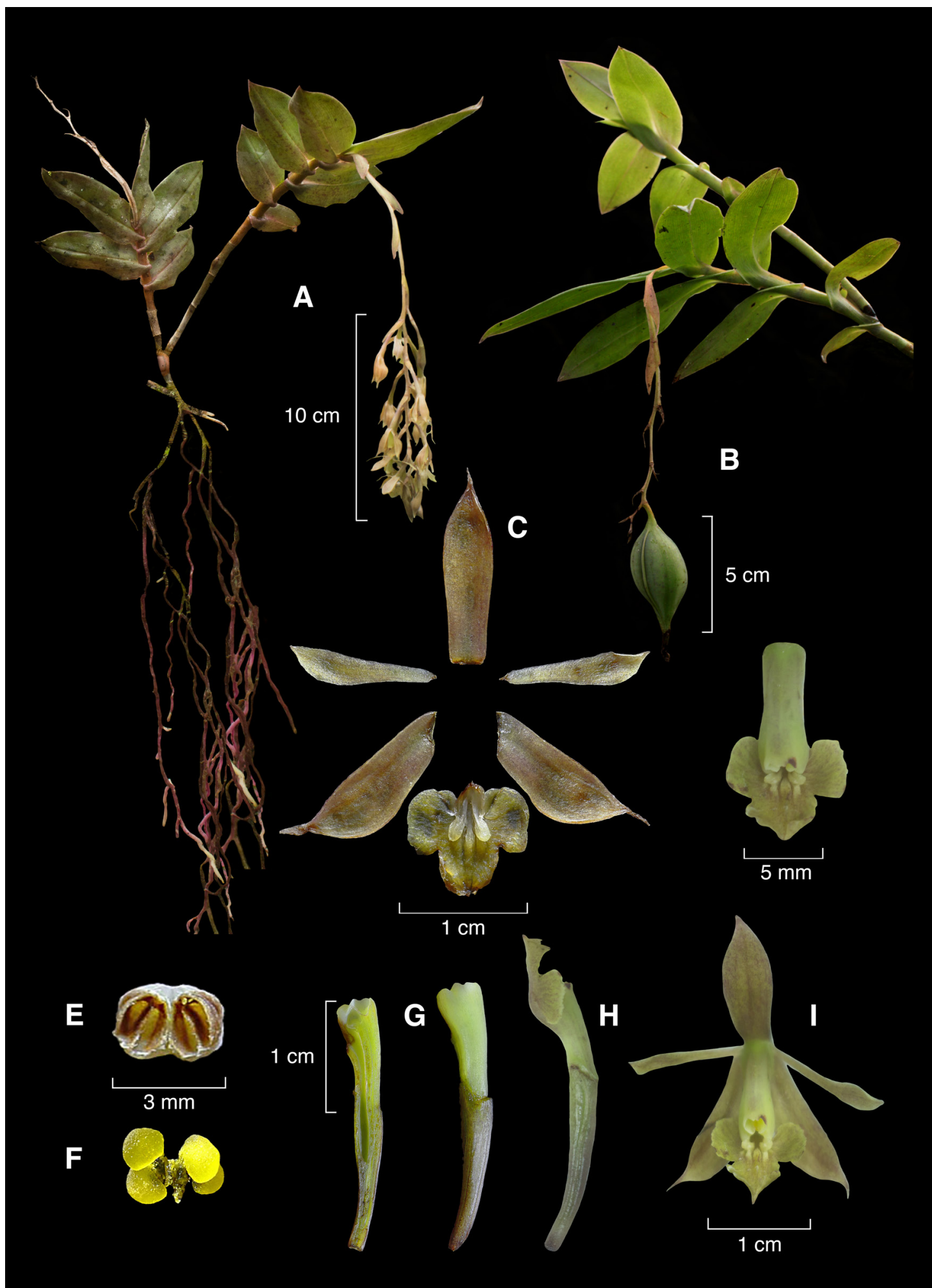


humid forest, epiphytic on Polylepis canoi, Oreopanax oroyanus, and Miconia sp., at $3450 \mathrm{~m}$ in elevation. Flowering in March.

Eтymology: In reference to the locality where the species was collected, in the basin of the Comunidad Campesina de Curimarca/Jauja.

Epidendrum curimarcense belongs to the Ampelospathum group which is recognized by the scandent habit, with new stems produced from the middle of the previous stems, roots produced at the base of the main stem, and occasionally from the base of the successive stems, an apical, arching, racemose inflorescence subtended by 1-2, large, acute spathes, and flowers with a 3-lobed lip with 2 small, basal calli. The new species has short plants, $c a .30 \mathrm{~cm}$ tall, elliptic leaves 2.5-7.3 × 1.0-2.5 cm, a nutant inflorescence, an elongate, ancipitose peduncle with a spathe, $2.3 \times 0.5$ $\mathrm{cm}$, that is conduplicate and acuminate with similar but progressively smaller bracts spaced along the peduncle, flowers greenish buff, column and lip green, sepals $16 \times 4-5 \mathrm{~mm}$, and a lip 3-lobed, the base slightly cordate, lateral lobes transversely ovoid, rounded, midlobe sub-quadrate and the apex rounded. Epidendrum ampelospathum has plants up to $2.5 \mathrm{~m}$ tall, the stems with only 5-7 narrowly lanceolate leaves, $11.2-18.5$ $\times 1.3-1.6 \mathrm{~cm}$, and yellow to yellowish green flowers with very wide, trullate petals, and a 3-lobed lip, the base deeply cordate, lateral lobes reniform, obliquely orbicular, rounded, the mid-lobe triangular, apex truncate, rounded. Epidendrum ampelomelanoxeros Hágsater, E.Santiago \& E.Parra has plants to $70 \mathrm{~cm}$ tall, a raceme with 17-26 flowers that are simultaneous, fleshy, greenish yellow tinged reddish, sepals 16-18 $\mathrm{mm}$ long, petals obliquely oblanceolate, acute, and dolabriform lateral lobes of the lip with the apical margin erose. Epidendrum totoroense has short, erect stems produced from the base of the previous stem, to 7.5 $\mathrm{cm}$ tall, with 2-4 elliptic leaves, $2.5-5.0 \times 1.3-2.0 \mathrm{~cm}$, an erect inflorescence $13.5 \mathrm{~cm}$ long, flowers yellowish brown with the apex of the column and disc tinged purple, sepals $19 \mathrm{~mm}$ long, and the lateral lobes of the lip smaller than the mid-lobe; the flowers are very similar to those of the new species in color and proportions, but the plant habit is clearly different.

Acknowledgements. We thank the Servicio Nacional Forestal y de Fauna Silvestre for providing authorizations for research under the R.D.G. No 037-2017-SERFOR/ DGGSPFFS, and to Patricia Harding for the language edition.

\section{LiTERATURE CITED}

Acuña-Tarazona, M. E., Hágsater, E. \& Santiago, E. (2019). Epidendrum choccei (Orchidaceae), a new species from Northern Peru. Phytotaxa, 394(1), 98-104.

AMODATA. (2019). Digital database of the Herbario AMO, Instituto Chinoin, México City, Mexico. [Accesed in October 2019].

Brako, L. \& Zarucchi, J. L. (1993). Catálogo de las Angiospermas y Gimnospermas del Perú. Monography Systematic Botany Missouri Botany Garden, 45, 1-1286.

Damian, A. \& Hágsater, E. (2016). Epidendrum yanatilense (Orchidaceae: Laeliinae), a new species, from Cusco, Peru. Phytotaxa, 246(4), 287-292.

Fjeldså, J. \& Kessler, M. (2004). Conservación de la biodiversidad de los bosques de Polylepis de las tierras altas de Bolivia. Una contribución al manejo sustentable en los Andes. Santa Cruz de la Sierra, Bolivia: Editorial FAN, DIVA Technical Report 11.

García, N. \& Galeano, G. (Eds.). (2006). Libro Rojo de Plantas de Colombia. Volumen 3: Las bromelias, las labiadas y las pasifloras. Serie de Libros Rojos de Especies Amenazadas de Colombia, Bogotá. Colombia: Instituto Alexander von Humboldt - Instituto de Ciencias Naturales de la Universidad Nacional de Colombia - Ministerio del Ambiente, Vivienda y Desarrollo Territorial. Retrieved from https://www.researchgate.net/publication/279204956_Libro_Rojo_ de_Plantas_de_Colombia_Volumen_3_Las_bromelias_las_labiadas_y_las_pasifloras

Goicochea, A., Gutiérrez, A., Ruiz, A. \& Salas, M. (2019). Orquídeas de Perú: Relación de especies y sus sinónimos (1st ed., pp. 288). Moyobamba, Peru: Corporación G Y G E.I.R.L.

Gutiérrez, H., Castañeda, R. \& Nauray, W. (2019). Epidendrum suinii (Orchidaceae: Epidendroideae) un nuevo registro para la flora peruana. Revista Peruana de Biología, 26(2), 271-274. 
Hágsater, E. \& Dodson, C. H. (2004). Epidendrum ampelospathum Hágsater et Dodson, sp. nov. In: E. Hágsater \& L. Sánchez (Eds.), The Genus Epidendrum Part 4, Icones Orchidacearum, 7: Plate703. Retrieved from http://epidendra. org/taxones/Epidendrum/Epidendrum\%20ampelospathum/Epidendru\%20ampelospathum\%20PROT.pdf

Hágsater, E. \& Soto, M. A. (2005). Epidendrum. In: A. M. Pridgeon, P. J. Cribb, M. W. Chase \& F. N. Rasmussen (Eds.), Genera Orchidacearum, 4: Epidendroideae (Part 1) (pp. 236-251). Oxford, England: Oxford University Press.

Hágsater, E., Santiago, E., \& Parra, E. (2013). Epidendrum ampelomelanoxeros. In: E. Hágsater. \& L. Sánchez (Eds.), The Genus Epidendrum Part 10, Icones Orchidacearum, 14: Plate 1405.

Hágsater, E. \& Santiago, E. (Eds.). (2018a). The genus Epidendrum, Part 12. Species new \& old in Epidendrum. Icones Orchidacearum, 16(1), plates 1601-1667 Retrieved from: http://www.herbarioamo.org/index_archivos/Fascicle16(1).pdf Hágsater, E. \& Santiago, E. (Eds.). (2018b). The genus Epidendrum, Part 12. Species new \& old in Epidendrum. Icones Orchidacearum, 16(2), plates 1668-1700. Retrieved from: http://www.herbarioamo.org/index_archivos/Fascicle16_2.pdf

Hágsater, E. \& Santiago, E. (Eds.) (2019). The genus Epidendrum, Part 13. Species new \& old in Epidendrum. Icones Orchidacearum, 17(1), plates 1701-1756. Retrieved from: http://www.herbarioamo.org/index_archivos/Fascicle17_1.pdf Kessler, M. (2006). Bosques de Polylepis. In: R. M. Moraes, B. Øllgaard, L. P. Kvist, F. Borchsenius \& H. Balslev (Eds.), Botánica Económica de los Andes Centrales (pp. 110-120). La Paz, Bolivia: Universidad Mayor de San Andrés.

Linnaeus, C. (1763). Species Plantarum, ed 2. 2: 1347. Retrieved from https://biodiversitylibrary.org\&page/11834734.

Moreno, J. S., Hágsater, E. Santiago, E. \& Erazo, A. L. (2016). Epidendrum totoroense. In: E. Hágsater \& L. Sánchez (Eds.), The Genus Epidendrum, Part 11. Species new \& old in Epidendrum. Icones Orchidacearum, 15(2), Plate 1589. Retrieved from: http://www.herbarioamo.org/index_archivos/Fascicle15(2).pdf

Roque, J. \& León, B. (2006). Orchidaceae endémicas del Perú. El libro rojo de las plantas endémicas del Perú. Revista Peruana de Biología, Número especial, 13(2), 759s-878s.

Ruiz, H. \& Pavón, J. A. (1798). Systema Vegetabilium Florae Peruvianae et Chilensis. Madrid, España: Typis Gabrielis de Sancha.

Santiago, E., \& Hágsater, E. (2019). Lecture, El Género Epidendrum con énfasis en el grupo macrostachyum, II Congreso Peruano de Orquideología, Moyobamba, October 2019.

Ulloa, C. (2019). Orchids from Peru. In: C. Ulloa Ulloa, P. Acevedo-Rodríguez, S. Beck, M. J. Belgrano, R. Bernal, P. E. Berry, L. Brako, Ma. Celis, G. Davidse, R. C. Forzza, S. R. Gradstein, O. Hokche, B. León, S. León-Yánez, R. E. Magill, D. A. Neill, M. Nee, P. H. Raven, H. Stimmel, M. T. Strong, J. L. Villaseñor, J. L. Zarucchi, F. O. Zuloaga \& P. M. Jørgensen (2018 onwards), Vascular Plants of the Americas (VPA) Website. Tropicos, Botanical Information System at the Missouri Botanical Garden, St. Louis, Missouri, USA. Retrieved from http://www.tropicos.org/Project/ VPA [Accessed 25/11/2019].

Ulloa, C., Acevedo-Rodríguez, P., Beck, S., Belgrano, M. J., Bernal, R., Berry, T. E., Brako, L., Celis, M., Davidse, G., Forzza, R. C., Gradstein, S. R., Hokche, O., Léon, B., Léon-Yánez, S., Magill, R. E., Neill, D. A., Nee, M., Raven, P. H., Stimmel, H., Strong, M. T., Villaseñor, J. L., Zarucchi, J. L., Zuloaga, F. O. \& Jørgensen, P. M. (2017). An Integrative assessment of the vascular plant species of the Americas. Science, 358, 1614-1617. Supplementary Materials: DOI: 10.1126/science.aao0398.

Ulloa, C., Zarucchi, J. L. \& León, B. (2004). Diez años de adiciones a la flora del Perú: 1993-2003. Arnaldoa, Edición Especial, 7-242. 
